日臨外会誌 $63(5), 1166-1170,2002$

症例

TAE，肝切除を加えた胃全摘術が有効であった多発性肝転移を伴う $\mathrm{AFP}$ 産生胃癌の 1 例

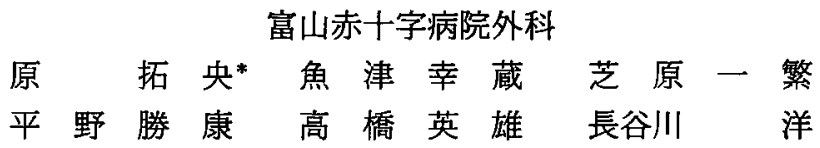

症例は52歳，女性. 吐血のため当院へ担送され，上部消化管内視鏡検査で胃角部前壁 に直径 $3 \mathrm{~cm}$ 弱のボタン状の隆起と, その肛門側に II a 様の広範な粗大顆粒状变化の拡が りを示す 5 型の病変を認めた。 また CT で肝 S 4 に 1 個, S 7 に 2 個の転移巣を認め, 術 前に肝動脈塞栓術を施行した。さらに血液検査で AFP $1,398 \mathrm{ng} / \mathrm{ml}$ の高值を認めた。手 術は胃全摘, D 2 リンパ節郭清および肝右葉切除と S 4 部分切除を行った. 組織学的に胃 病変は粗大顆粒状の部分が tub 1 , 隆起性病変の部分は por 1 を主体で免疫染色にて AFP 陽性であった。深達度はMPで，1群リンパ節に転移を認めた。 AFP は約 2 カ月 後に正常範囲へ低下し, 術後18力月の現在再発の徴候を認めていない. AFP 産生胃癌の 肝転移陽性例は予後不良とされているが,積極的な外科的切除が有効な 1 例を経験した。

索引用語：多発肝転移を伴う AFP 産生胃癌, 肝動脈塞栓術, 外科的切除

はじめに

胃癌症例のごく一部ながら AFP の著しい高値を伴 ういわゆる AFP 産生胃癌は非産生胃癌に比べ生物学 的悪性度が高く，同時性・異時性を問わず高率に肝転 移を生じ，一般的に生命予後は不良とされている11.

今回われわれは両葉にわたる多発性肝転移を伴った AFP 産生胃癌に対し, 肝動脈塞栓術（以下 TAE）に 引き続き一期的切除を行い18力月無再発の 1 例を経験 したので報告する。

\section{症例}

症例 : 52歳, 女性.

既往歴，家族歴：ともに特記すべきことなし。

現病歴：2000年 2 月 12 日に誘因なく吐血を認めたた め当院へ救急担送された。全身状態は安定していたが, 精查目的に入院となった.

入院時現症：身長 $157 \mathrm{~cm}$, 体重 $45 \mathrm{~kg}$, 脈拍 $72 /$ 分, 血 圧 $134 / 60 \mathrm{mmHg}$. 顔面蒼白て眼瞼結膜は筫血様. 腹部 は平坦・軟で若干の腸雑音の元進を認めたが，圧痛や

2001 年 9 月 25 日受付 2002 年 2 月 8 日採用

*現：厚生連高岡病院外科

〈所属施設住所〉

干930-0859 富山市牛島本町 2-1-58
腹膜刺激症状はなく腫瘤も触知されない。

入院時検査成績: 胸腹部単純写真では異常所見を認 めなかった，血液検查では WBC $11,900 / \mathrm{mm}^{3}$ と白血 球增多を認め, $\mathrm{Hb} 8.7 \mathrm{~g} / \mathrm{dl}$ の筫血の状態であった。一 般生化学検査に異常值は認めなかった。腫場マーカー は AFP が1,398ng/ml と高值で, HCG は1,2mIU $/ \mathrm{ml}$ (正常0.7以下) と若干の上昇を認めた. CEA, CA199は正常範囲内であった。

内視鏡検査: 上部消化管内視鏡で胃角部前壁に出血 を伴う $3 \mathrm{~cm}$ 大の, その大彎側にも $1 \mathrm{~cm}$ 大の隆起性病 変があり, それより肛門側に退色調の粗大顆粒状病変 の拡がりを認めた(図 1 )。生検ではいずれの部位から も tub 1 を主体とする胃癌を認めた。また胃透視でも 同样の病変が描出され，全体として 5 型の胃癌と診断 した (図 2 )。

腹部 CT, 腹部血管造影：肝 S 4 に 1 個，S 7 亿2 個 の $3 \sim 4 \mathrm{~cm}$ 大の腫㿔影を認めた. 動脈相で濃染, 静脈 相では low density を示し, 肝細胞癌類似の転移巣と 診断した。このため血管造影時に A 4 およびA 7 より Lipiodol の動注後 TAEを施行した（図3）.

手術所見：TAEの17日後に手術を行った. 生検に て病変隆起部の口側粘膜に異常のないことを確認して いたため,まず D 2 郭清の幽門側胃切除術を行ったが, 


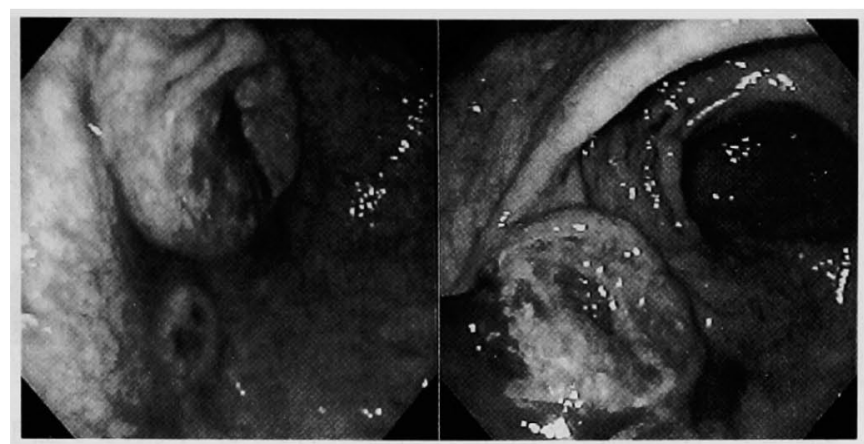

図 1 上部消化管内視鏡：胃角部前壁に出血を伴う $3 \mathrm{~cm}$ 大，その大 榒側にも $1 \mathrm{~cm}$ 大の隆起性病変があり (左)，それより肚門側に退色 調の粗大顆粒状病変の拡がりを認めた（右).

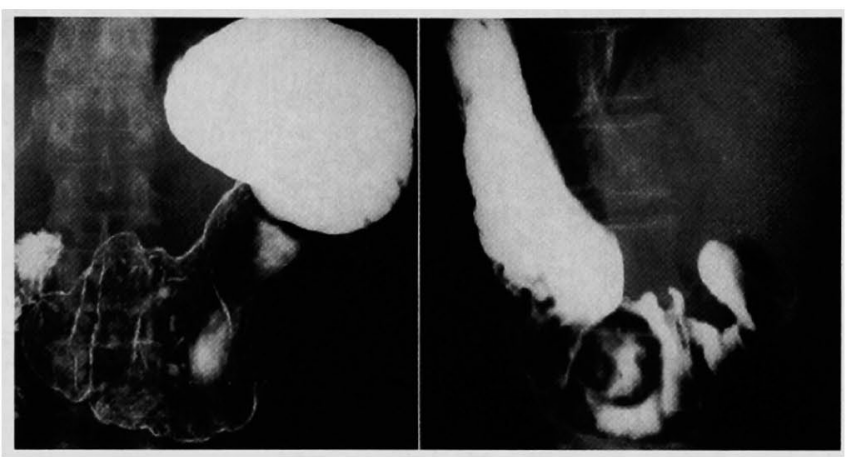

図 2 胃透視：上部消化管内視鏡と同様の所見で、全体として 5 型の 胃癌と診断した。

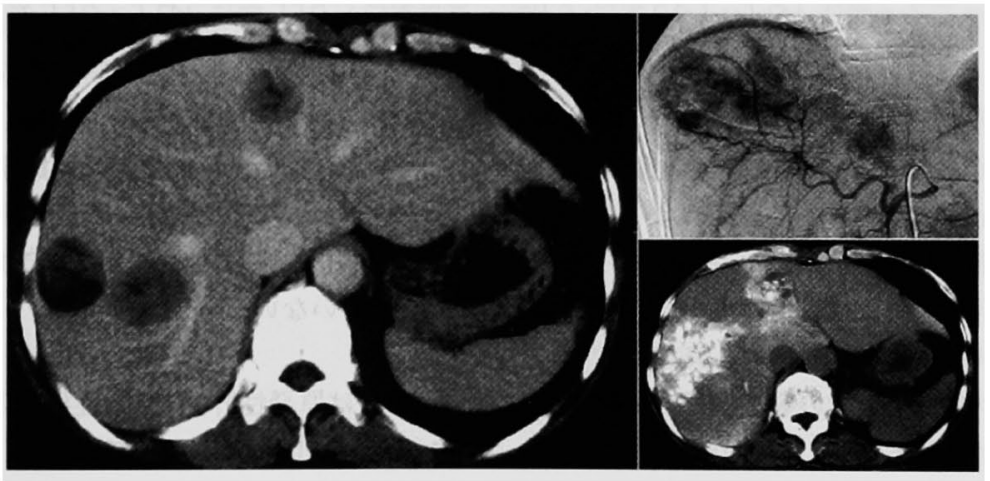

図 3 腹部 CT, Angio, TAE : 肝 S に 1 個, S 7 に 2 個の low density を示す 腫瘤影を認めた。造影に上り動脈相で浱染し，静脈相では low density を示し た(左)。血管造影では早期より濃染し（右上），Lipiodolの動注後 A †および A 7 より TAEを施行した（右下）.

術中ゲフリールにてロ側断端の粘膜下に腫湯細胞の遺 残を指摘され，追加切除により結果的に胃全摘術とな った. 次いで胆衰切除の後, 肝右葉切除と S40部分切
除を行った. 手術所見は T2N1H1P0M0で根治度 B で あった。

切除標本：胃角部前壁に $3.6 \mathrm{~cm}$ 大の隆起性病変が 


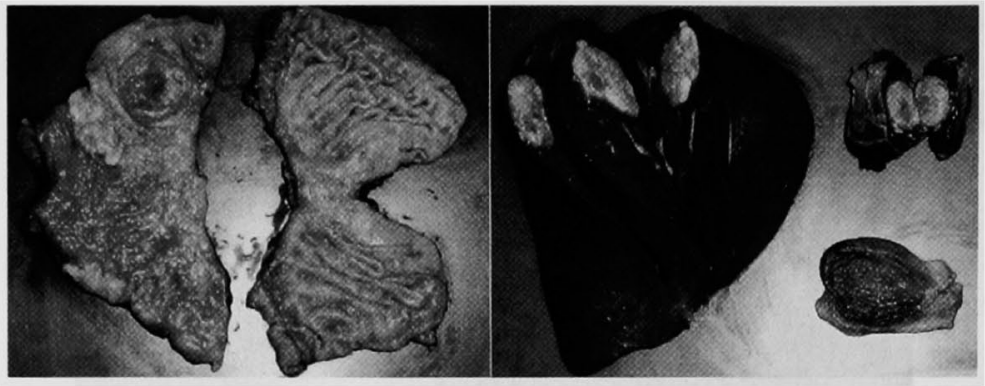

図 4 切除標本：胃角部前壁に $3.6 \mathrm{~cm}$ 大の隆起性病変があり,それより肛門側に II a 様で退色調の粗大顆粒状病変が㹡がる $8.5 \times 6.2 \mathrm{~cm}$ 大の 5 型の胃癌を認め る. 肝は $\mathrm{S} 4$ に直径 $2.5 \mathrm{~cm}$ 大, $\mathrm{S} 7$ に $3.6 \mathrm{~cm}$ おるび $3.4 \mathrm{~cm}$ 大の黄色調を示す腫 瘍性病変を認めた。

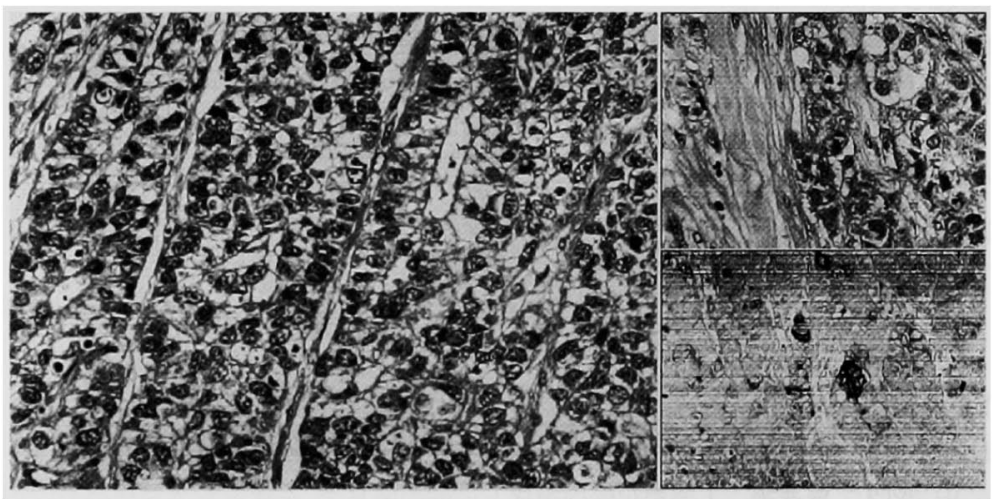

図 5 病理組織所見： 5 型癌の巨大な隆起性病変の部分は粘膜下層で髄様増殖を 呈する por 1 で(左：HE染色, $\times 100)$ ，この por 1 の部分はPAS 染色でグリコ ーゲン陽性（右上：PAS 染色，×100），兔疫染色で AFP陽性（右下：AFP免 疫染色, ×100) であった。

ありそそれより肛門側にII a 様で退色調の粗大顆粒状 病変が拡がる $8.5 \times 6.2 \mathrm{~cm}$ 大の 5 型の胃癌を認める. 肝は S 4 に直径 $2.5 \mathrm{~cm}$ 大, S 7 に $3.6 \mathrm{~cm}$ および3. $4 \mathrm{~cm}$ 大の黄色調を示す腫瘍性病変を認めた（図 4).

組織学的所見：組織学的には 5 型胃癌の肛門側に拡 がるII a 様の部分が tub 1 を主体とする表在病変で， 隆起性病変の部分が粘膜下層での暍道様増殖を主体とす る肝細胞癌様の por 1 であった。この por 1 の部分は PAS 染色でグリコーダン陽性, 免疫組織化学的に AFP 陽性であった（図 5 )。媣達度はMPで，脈管侵 㢣は $1 \mathrm{y} 1, \mathrm{v} 1$, リンパ節はNo. 3 および $4 \mathrm{~d}$ に計 6 個 の転移を認めた。肝転移巣はTAEにより一部が壊死 に陥っていたが，いずれも原発巣の por 1 の部分と類 した構造を示し,免疫組織化学的に原発巣と同様 AFP 陽性であった。

術後は良好に経過し第30病日に退院となった。当初
化学療法は拒否されたがテガフールーウラシル合剤の 内服を同意頂き，外来で経過観察中である。AFPは約 2 力月かかって正常範囲へ低下し, 術後18力月目の現 在も 1 标を維持している．またこの他にも再発の徴候 を認めていない。

\section{考 察}

AFP は原発性肝癌, 胎児性癌などで高值を示す腫場 マーカーとして用いられているが，本来胎児 yolk sac より産生される糖蛋白で胎生期の胃粘膜にもその産生 能があると言われている2). AFP 産生胃癌は術前より 血清 AFP が異常な高值を示し胃癌の消長と相関する こと, 組織学的に AFP の局在が証明されることなど によって規定されるが，1970年の Bourreille 以来数多 くの報告があり，胃癌症例の1.8-8.8\%が AFP 産生性 であるとされているい゙51.

一般に AFP 産生胃癌の特徵として肉眼型は 2 ない 
し 3 型，組織学的には䯣梯構造をとることが多く，特 に AFP 産生部位ではしばしば肝細胞癌と類似する構 造が見られる. 臨床的には早い時期から肝転移，リン 八幯転移を生じるとされ，特に肝転移陽性例は同時性， 異時性を合わせ, 60.9-73.7\%を占めると報告されてい $3^{4) 6}$. 肝転移陽性例では良好な予後は望めず, 小林ら は平均生存期間で13.5力月, 岩崎 ら ${ }^{8)}$ は 1 年生存率 $46.2 \%, 3$ 年生存率 $5.7 \%$ と報告している。また本邦に 抢ける 5 年以上の長期生存例の報告は 1 例の非切除例 を含めて 3 例にとどまっている57799.

しかし AFP 産生胃癌は化学療法への感受性が比較 的高いとされ，積極的に強力な方法で加療している報 告例が数多く見られる。また肝転移巣は肝細胞癌と同 様に肝動脈より優位に血液供給を受けるため造影によ る動脈相での濃染という特徵を有し, 長期生存症例の 報告からも TAEを単独または肝切除術前に行うこと で（微少・末発見のものを含めた）転移巣を効果的に コントロールできる可能性が考えられる5199.

本例は進行胃癌に同時性の両葉にわたる肝転移例で 当初良好な予後は期待できないと考えられたが, 主病 巣からの出血をコントロールする必要があったこと， 肝予備能が良好であったこと, 肝転移巣が動脈相で強 〈造影され TAE の効果が期待できたこと，化学療法 を拒否されていたことなどの理由により，慎重に手術 適応と判断した. 現在テガフールーウラシル合剤の内服 で経過観察中であるが注射による化学療法は一切行っ てうらず，注意深い経過観察が必須であることはもち ろん再発した場合の追加療法にも熟慮を要すると考え ている.

手術適応の有無は慎重に決定する必要があるが，本 例の経験から多発肝転移を伴った AFP 産生胃癌でも $\mathrm{TAE}$ ともに積極的な切除が有効である可能性が示 晙された.

\section{結 語}

多発性肝転移を伴った AFP 産生胃癌に対し, TAE と一期的切除を行い, 術後18力月無再発の1例を経験 したので若干の文献的考察を加え報告した.

\section{文 献}

1）高橋 豊, 磨伊正義, 荻野知已他：AFP 産生胃癌 の臨床病理学的検討一胃癌における AFP の意義 一. 日外会誌 $88: 696-700,1987$

2) 加藤 拓, 高橋久雄, 井田喜博他: AFP 産生胃癌 の免疫組織化学的検討一特 $R$ AFP 陽性細胞の形 態と性格について一。臨病理 $41 ： 1024-1030$, 1993

3) 稲田高男, 井村䆏二, 尾形佳郎他: Alpha-fetprotein 産生胃癌に対する臨床病理学的抢よび增 殖活性についての恰討. 日消外会誌 $26 ： 979-$ 983, 1993

4）露木 茂, 仁尾義則, 井上一知他：肝転移巣に alpha-fetprotein 陽性細胞を認めた多発進行胃艆 の 1 切除例. 日消外会誌 $24: 1042-1046 ， 1991$

5）高橋直典, 手島 伸, 國井康男: 集学的治療が奏 効し長期間生存している AFP 産生胃癌多発肝転 移の 1 例. 日消外会誌 $32: 846-850,1999$

6) 権田 剛, 石田秀行, 书口哲郎他：EAP 療法が著 効を示した AFP 産生胃癌肝転移の 1 例. 癌と化 療 $21: 1659-1663,1994$

7）小林泰三，広瀨和郎，新本修一他：TAE が著効し た AFP 産生胃癌肝転移再発の 1 例。癌と化療 $23: 1705-1708,1996$

8）岩崎 誠, 山際健太郎, 草川雅之他：AFP おょび CA19-9産生胃癌の 1 例. 日臨外会誌 $54: 3056-$ 3060, 1993

9）石岡達司, 筆井 格, 三好 毅他：癌化学療法で 5 年以上生存している多発性肝転移を伴った進行 胃癌の 1 例。日癌治療会誌 $30: 75-81,1995$ 


\title{
A CASE OF AFP-PRODUCING GASTRIC CANCER ASSOCIATED WITH MULTIPLE HEPATIC METASTASIS WHICH TOTAL GASTRECTOMY AND HEPATECTOMY AFTER TAE WERE EFFECTIVE
}

\author{
Takuo HARA, Kozo UOZU, Kazushige SHIBAHARA, \\ Katsuyasu HIRANO, Hideo TAKAHASHI and Hiroshi HASEGAWA \\ Department of Surgery, Toyama Red Cross Hospital
}

\begin{abstract}
A 52-year-old woman was brought because of hematemesis. Upper gastrointestinal endoscopic study revealed a type 5 lesion which showed a button like elevation a little less than $3 \mathrm{~cm}$ in diameter at the anterior wall of the gastric angle and, on its anal side, a Ila like extending coarse granular change. Abdominal CT scan revealed a metastatic lesion in liver S4 and two lesions in S7. Hematological study showed a high level of AFP, $1,398 \mathrm{ng} / \mathrm{ml}$. Transarterial embolization was performed preoperatively. Operative procedure included a total gastrectomy with $\mathrm{D} 2$ lymph node dissection, a right lobectomy of the liver, and a segmentectomy (S4). Histological study of the gastric lesion disclosed that the coarse granular part was tubl and the elevated lesion was mainly composed of porl which was AFP positive immunologically. The invasion depth of the tumor was MP and metastasis to the group 1 lymph nodes was confirmed. AFP level was normalized in about 2 months and no signs of recurrence have been observed as of 18 months after the operation.

Although it is believed that AFP-produsing gastric cancer with hepatic metastasis has a poor prognosis, we have experienced the case in which active surgical resection was benefical for the patient.
\end{abstract}

